\title{
PENTAALKYL-6-TRIORGANOSTANNYL- $2,3,4,5$-TETRACARBA-NIDO-HEXABORANES(6)
}

\author{
Bernd Wrackmeyer* and Alexandra Glöckle \\ Anorganische Chemie II, Universität Bayreuth, , D-95440 Bayreuth, Germany
}

\begin{abstract}
Pentaalkyl-6-bromo-2,3,4,5-tetracarba-nido-hexaboranes(6) (carb- $\mathrm{Br}$ 2) react with trimethylstannyl- and triphenylstannyl-lithium to give the 6-stannyl subtituted carbaboranes carb-SnMe 3 3a and carb-SnPh $3 \mathbf{3 b}$. The reactivity of $3 \mathbf{b}$ towards various electrophiles was studied. It reacts with tin tetrachloride and tin tetrabromide preferably by cleavage of the $\mathrm{Sn}-\mathrm{C}$ bond, leading finally to novel inorganic tin(IV) halides carb-SnCl ${ }_{3} 6(\mathrm{Cl})$ or carb- $\mathrm{SnBr}_{3} 6(\mathrm{Br})$. This is also true for the reaction with boron tribromide. In this case, carb- $\mathrm{SnBr}_{3} 6(\mathrm{Br})$ proved to be stable even in the presence of an excess of $\mathrm{BBr}_{3}$; heating of this mixture at $60^{\circ} \mathrm{C}$ leads back to 2 and to $\mathrm{SnBr}_{2}$. In the reaction with bromine, it appears that both $S n-C$ and $S n-B$ bonds are attacked since the formation of carb-SnPh $\mathrm{S}_{2} \mathrm{Br} 4(\mathrm{Br})$, carb-SnPhBr${ }_{2} 5(\mathrm{Br})$ and 2 can be detected by ${ }^{119} \mathrm{Sn}$ and ${ }^{11} \mathrm{~B}$ NMR. No reaction of $\mathbf{3 b}$ with zirconium tetrachloride was observed, whereas titanium tetrachloride reacts very slowly, aaain by cleavage of one of the $\mathrm{Sn}-\mathrm{C}$ bonds. All products were characterized by ${ }^{1} \mathrm{H}$, ${ }^{11} \mathrm{~B},{ }^{13} \mathrm{C}$ and ${ }^{119} \mathrm{Sn}$ NMR spectroscopy.
\end{abstract}

\section{Introduction}

Although peralkylated 2,3,4,5-tetracarba-nido-hexaboranes(6) have been known since the mid-sixties [1] as exceptionally stable compounds (in contrast with the parent derivative $\mathrm{C}_{4} \mathrm{~B}_{2} \mathrm{H}_{6}$ [2]), their chemistry has not been explored in great detail. Only recently, the synthesis of tetraalkyl1,6-dibromo- [3] and pentaalkyl-6-bromo-derivatives [4] was reported, together with the corresponding $\mathrm{B}-\mathrm{H}$ derivatives, and the basic structure of such alkylated carbaboranes determined by an X-ray diffraction analysis of another pentamethyl derivative with the $\mathrm{N}$-bonded $\mathrm{Fe}_{2}(\mathrm{CO})_{6}-\mu$ SN fragment in 6-position [5]. Various polyhedral boranes are known in which triorganostannyl groups are linked to boron either in bridging or in terminal position [6]. The synthetic potential of simple stannylboranes [7] is increasing since it was found that compounds such as $\mathrm{Me}_{3} \mathrm{SnB}\left(\mathrm{NEt}_{2}\right)_{2}$ can be used in the palladium-catalyzed stannylboration of alkynes [8]. Therefore, we report in the present work on the synthesis of pentaalkyl-6-triorganostannyl-2,3,4,5-tetracarba-nidohexaboranes(6) 3 , together with the results of a first screening of the reactivity of 3 towards various element halides. 


\section{Results and discussion}

\subsection{Syntheses of 6-triorganotin substituted carbaboranes}

The most convenient route to peralkylated 2,3,4,5-tetracarba-nido-hexaboranes(6) is shown in Eq.(1), leading to a $2: 1$ mixture of isomers $1+1^{\circ}$ [1]. These isomers have almost identical physical and chemical properties, and therefore the mixture $1+1^{\circ}$ was used as starting material.

6<smiles>CCCCCCCC</smiles>

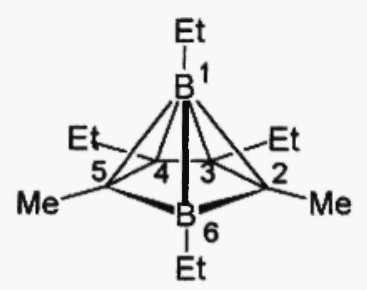

1

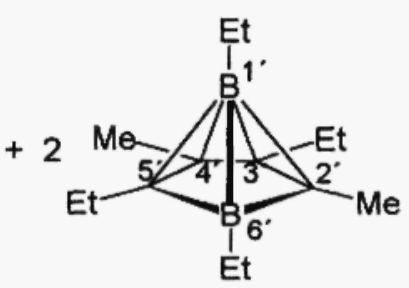

$1^{*}$

carb-Et

Following again the literature procedure [4], $1+1^{\circ}$ were converted selectively to $2+2^{*}$ by treatment with boron tribromide [Eq.(2)]. In the following the 6-substituted carboranyl moieties are abbreviated as carb.

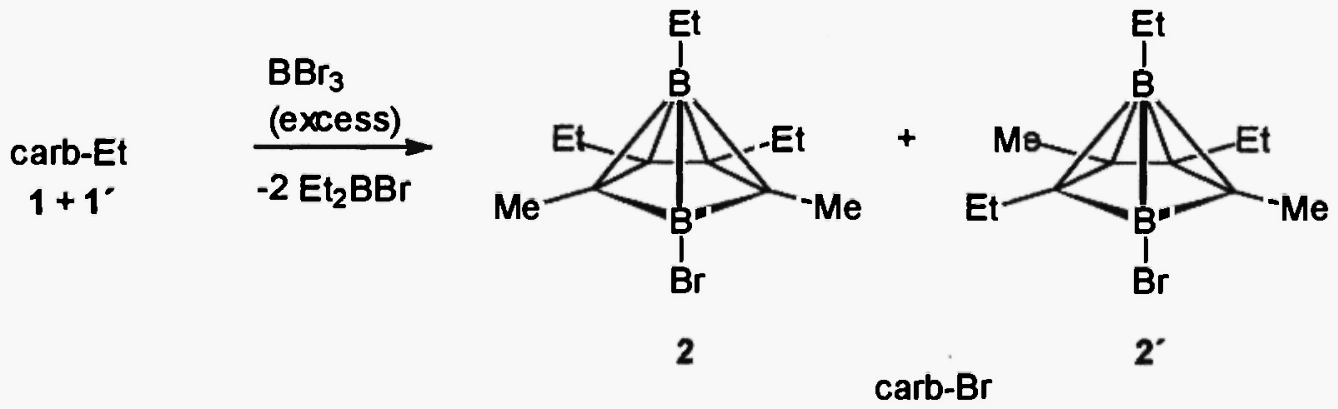

The reaction of the mixture $2+2^{\prime}$ with $\mathrm{Me}_{3} \mathrm{SnLi}$ or $\mathrm{Ph}_{3} \mathrm{SnLi}$ [Eq.(3)] in THF afforded the corresponding mixtures of carbaboranes $3+3^{\prime}$ in moderate to good yields.

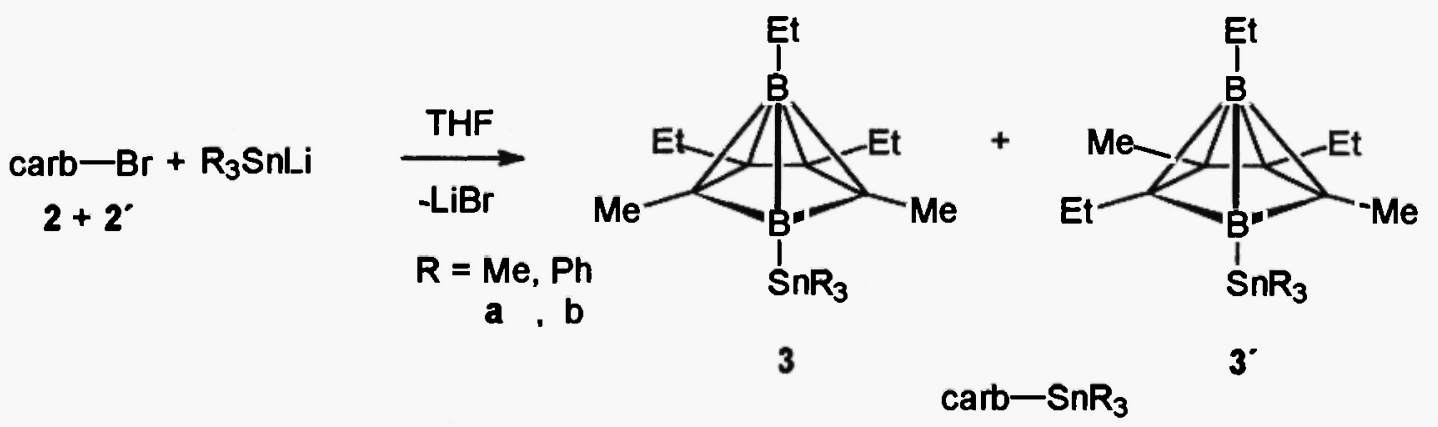




\subsection{Reactivity of $3 b+3 \mathrm{~b}$ towards electrophiles}

The reactivity of Sn-C bonds towards electrophiles is well documented [9]. Exchange reactions of tetraorganyltin compounds with tin tetrachloride or tin tetrabromide serve as prominent examples.

The course of the exchange reaction of $3 b+3 \mathbf{b}$ with tin tetrachloride (Scheme 1 ) is evident from the sequence of ${ }^{119} \mathrm{Sn} \mathrm{NMR} \mathrm{spectra} \mathrm{in} \mathrm{Figure} \mathrm{1.} \mathrm{The} \mathrm{first} \mathrm{reaction} \mathrm{products} \mathrm{are} \mathrm{carb-SnPh} \mathrm{Cl}_{2}$ $4(\mathrm{Cl})$ and carb-SnPhCl $25(\mathrm{Cl})$, together with $\mathrm{PhSnCl}_{3}, \mathrm{Ph}_{2} \mathrm{SnCl}_{2}$ and a trace of $\mathrm{Ph}_{3} \mathrm{SnCl}$ (Fig. 1a). This indicates that the $S n-C$ bonds are more reactive than the $S n-B$ bond. Only in the presence of an excess of $\mathrm{SnCl}_{4}$, the equilibrium is finally shifted towards carb-SnCl ${ }_{3} 6(\mathrm{Cl})$ (Fig. 1d) wich may be formed also by cleavage of the Sn-B bond. However, considering the product distribution in the beginning of the reaction, it is more likely that the cleavage of the third $\mathrm{Sn}-\mathrm{C}$ bond takes place much more slowly than the cleavage of the first and second $\mathrm{Sn}-\mathrm{C}$ bond, and may still be faster than the cleavage of the Sn-B bond. The reaction with an excess of $\mathrm{SnBr}_{4}$ (Scheme 1) leads to carb-SnPhBr $25(\mathrm{Br})$, even after heating for $12 \mathrm{~h}$ at $80^{\circ} \mathrm{C}$.

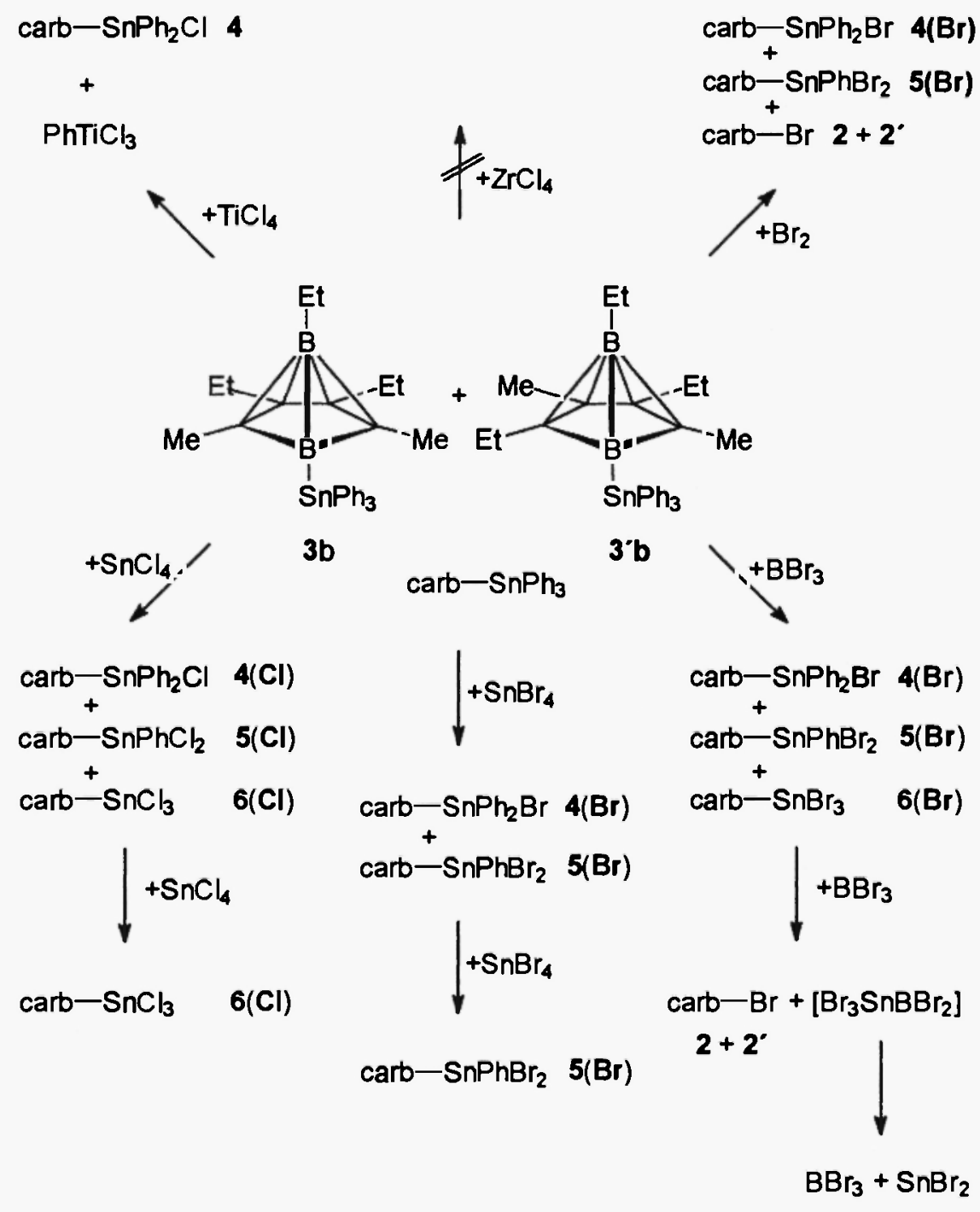

Scheme 1. Exchange reactions of carb-SnPh $33 b+3^{\circ} b$ with element halides (The tin halides $\mathrm{Ph}_{3} \mathrm{SnX}, \mathrm{Ph}_{2} \mathrm{SnX} \mathrm{X}_{2}, \mathrm{PhSn} \mathrm{X}_{3}$ have been omitted for clarity). 


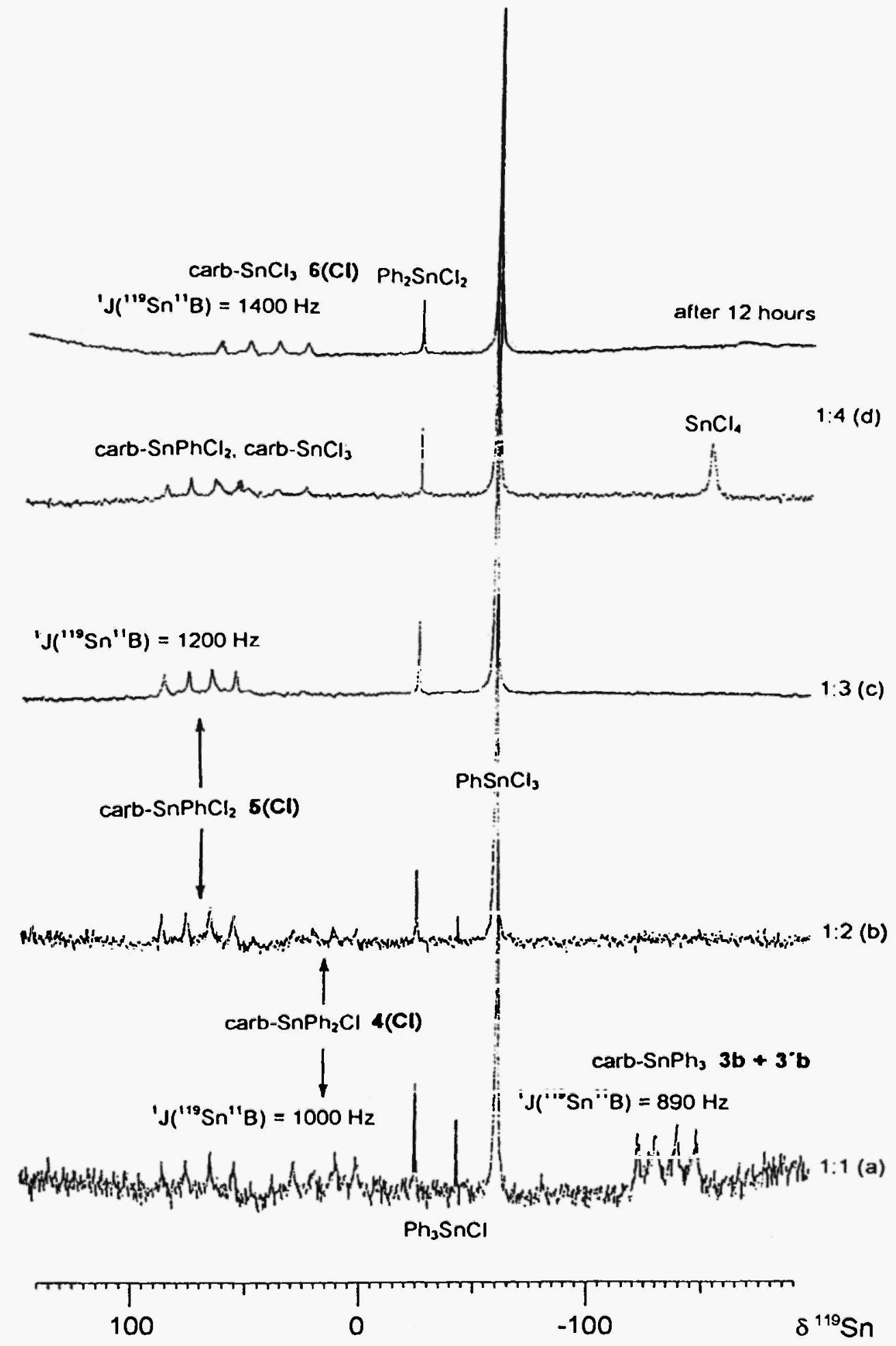

Figure 1. The exchange reaction of $3 \mathrm{~b}+3^{\circ} \mathrm{b}$ with $\mathrm{SnCl}_{4}$ monitored by $112 \mathrm{MHz}{ }^{119} \mathrm{Sn} \mathrm{NMR}$ [see text for (a) - (b)]. 
Similarly, $3 b+3^{\prime} \mathbf{b}$ react with $\mathrm{BBr}_{3}$ preferably by cleavage of the $\mathrm{Sn-C}$ bond (Scheme 1) to give carb- $\mathrm{SnBr}_{3} 6(\mathrm{Br})$ which is stable at room temperature, even in the presence of an excess of $\mathrm{BBr}_{3}$. Heating of such a mixture at $60^{\circ} \mathrm{C}$ for 6 hours leads to the formation of carb- $\mathrm{Br} 2+2^{\circ}$ and $\mathrm{SnBr}_{2}$.

The reaction of $3 b+3^{\prime} b$ with bromine gives carb-SnPh ${ }_{2} \mathrm{Br} 4(\mathrm{Br})$, carb-SnPhBr $25(\mathrm{Br})$ and carb- $\mathrm{Br} 2+2$, indicating cleavage of the $\mathrm{Sn}-\mathrm{C}$ as well as of the $\mathrm{Sn}-\mathrm{B}$ bond.

No reaction was observed between $3 \mathrm{~b}+3^{\prime} \mathrm{b}$ and $\mathrm{ZrCl}_{4}$, whereas $\mathrm{TiCl}_{4}$ reacts slowly to give carb- $\mathrm{SnPh}_{2} \mathrm{Cl} 4(\mathrm{Cl})$ and $\mathrm{PhTiCl}_{3}$

\subsection{NMR spectroscopic results}

The consistent data set of ${ }^{1} \mathrm{H},{ }^{11} \mathrm{~B},{ }^{13} \mathrm{C}$ and ${ }^{119} \mathrm{Sn}$ NMR data (see Table 1) supports the proposed structure of the 6-stannyl-carbaboranes.

The 2,3,4,5-tetracarba-nido-hexaborane(6) structure itself follows unambiguously from the typical $\delta^{11} \mathrm{~B}$ data for the apical $(\delta-43.3$ to -43.7$)$ and the basal boron atom $(\delta 11.3$ to 13.7$)$. The substituent pattern can be deduced from the $\delta^{13} \mathrm{C}$ values of the substituents, and most data could be assigned based on the results of $2 \mathrm{D}{ }^{1} \mathrm{H} /{ }^{1} \mathrm{H}$ COSY and $2 \mathrm{D}{ }^{13} \mathrm{C} /{ }^{1} \mathrm{H}$ HETCOR experiments. The marked broadening of the ${ }^{13} \mathrm{C}$ resonances of boron-bonded carbon atoms (see Figure 2) is an additional criterion for the assignment. The ${ }^{119} \mathrm{Sn}$ nuclear shielding in $3 a\left(\delta^{19} \mathrm{Sn}-117.1\right)$ or $3 \mathrm{~b}$ $\left(\delta^{119} \mathrm{Sn}-137.8\right)$ is significantly increased when compared with $\mathrm{Ph}-\mathrm{SnMe}_{3}\left(\delta^{119} \mathrm{Sn}-28.6\right)$ or $\mathrm{Ph}_{4} \mathrm{Sn}$ $\left(\delta^{119} \mathrm{Sn}-128.1\right)$. In contrast, the presence of $\mathrm{Cl}$ or $\mathrm{Br}$ at the tin atom reduces the ${ }^{119} \mathrm{Sn}$ nuclear shielding much more than in comparable phenyltin halides [e.g., $\delta^{119} \mathrm{Sn}+44.0(6(\mathrm{Cl}))$ and $\delta^{119} \mathrm{Sn}$ $-63.0\left(\mathrm{PhSnCl}_{3}\right)$, or $\delta^{119} \mathrm{Sn}-96.1(6(\mathrm{Br}))$ and $\left.\delta^{119} \mathrm{Sn}-224.6\left(\mathrm{PhSnBr}_{3}\right)\right]$. If one fits the $\delta^{119} \mathrm{Sn}$ values to pairwise additive parameters [12], strong deshielding interactions carb/Cl or carb/Br must be assumed, whereas carb/Me or carb/Ph interactions contribute to increased ${ }^{119} \mathrm{Sn}$ nuclear shielding.

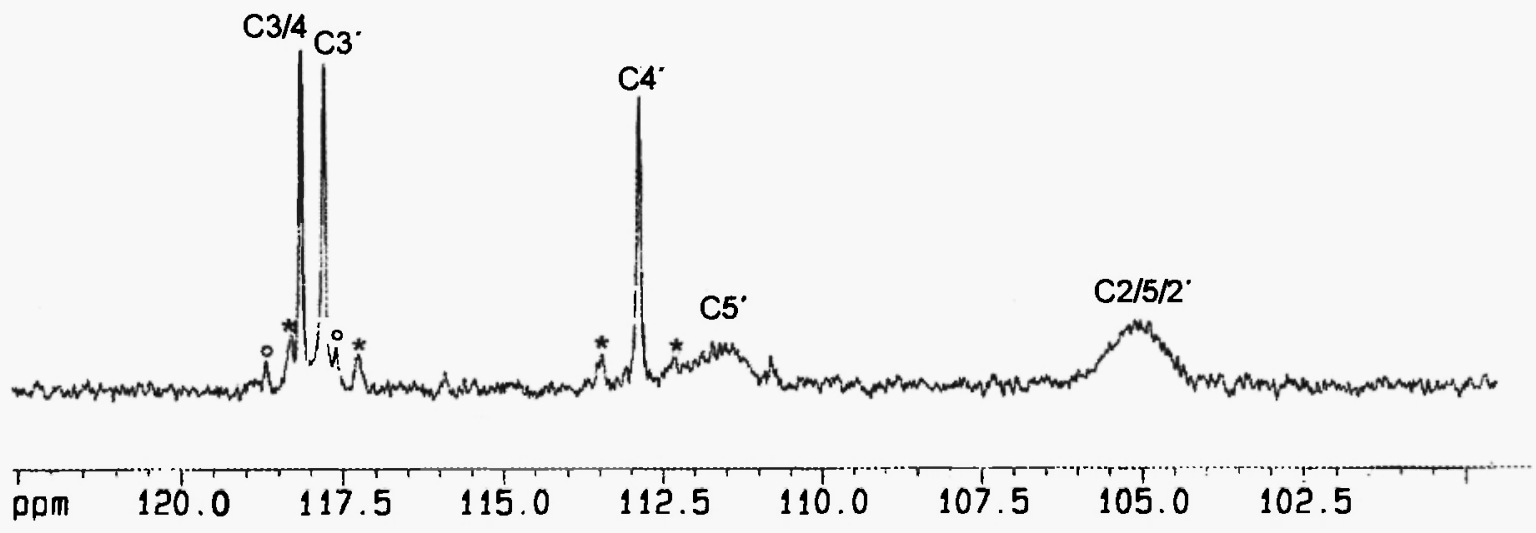

Figure 2. $125.8 \mathrm{MHz}{ }^{13} \mathrm{C}\left\{{ }^{1} \mathrm{H}\right\}$ NMR spectrum of carb-SnCl ${ }_{3} 6(\mathrm{Cl})$ showing the region for the carbaborane ${ }^{13} \mathrm{C}$ resonances with ${ }^{117 / 119} \mathrm{Sn}$ satellites (marked by asterisks) according to ${ }^{3} \mathrm{~J}\left({ }^{19} \mathrm{Sn},{ }^{13} \mathrm{C}\right)$. Note the broad ${ }^{13} \mathrm{C}$ resonance signals for the boron-bonded carbon atoms $\mathrm{C}(2 / 5)$.

The magnitude of the coupling constants $I^{1} \mathrm{~J}\left({ }^{119} \mathrm{Sn},{ }^{11} \mathrm{~B}\right) I$ in 3 is similar to that observed for simple stannylboranes [7] or polyhedral stannylboranes [6]. The magnitude of $I^{1} \mathrm{~J}\left({ }^{19} \mathrm{Sn},{ }^{11} \mathrm{~B}\right) \mathrm{I}$ increases with the number of halogen atoms attached to the tin atom, in particular in the series with $\mathrm{Cl}$. This is an expected trend and fits into the concept of rehybridization [13] at the tin atom, 


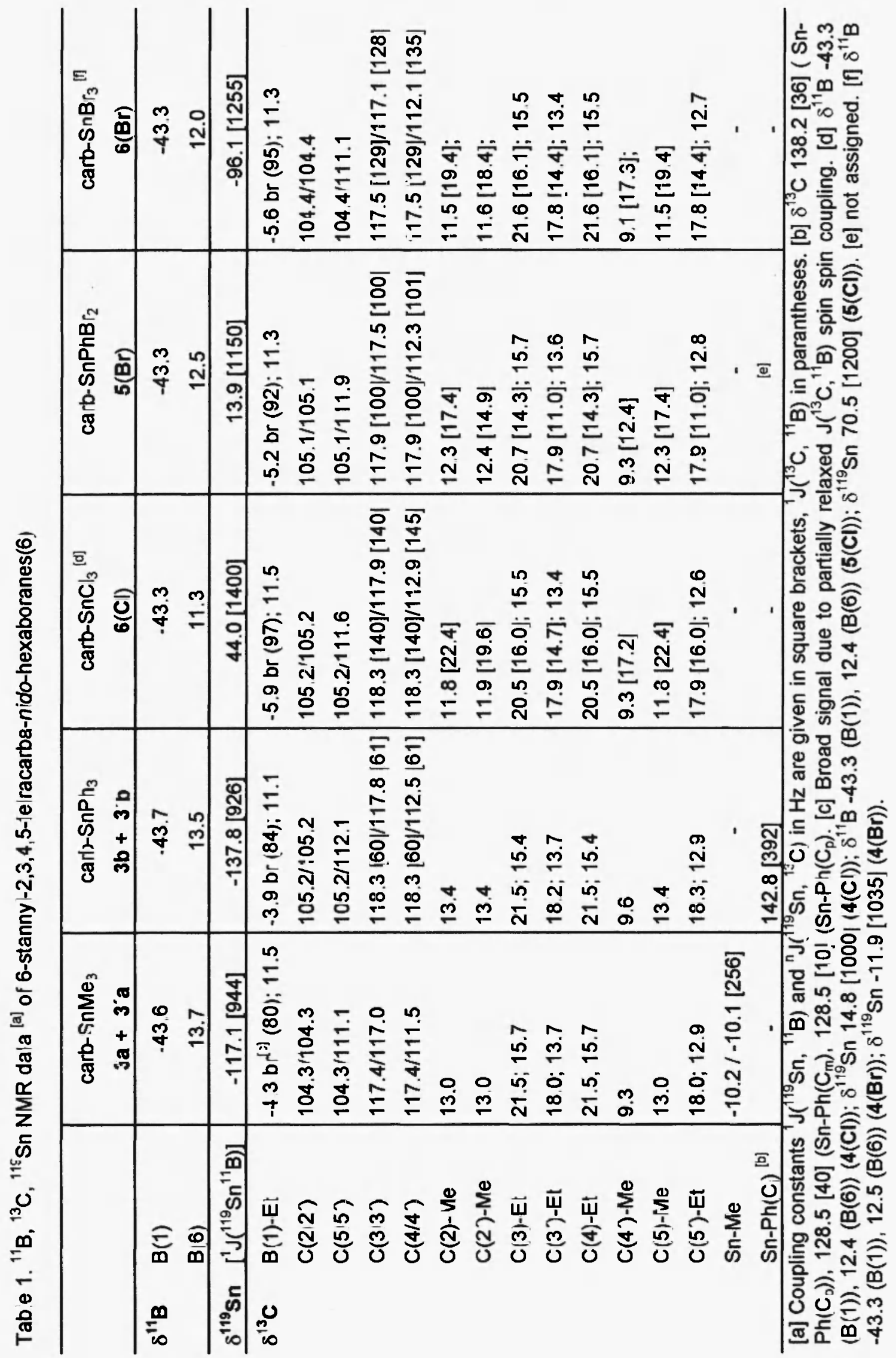


induced by strongly electronegative ligands. The smaller values of $I^{1} \mathrm{~J}\left({ }^{119} \mathrm{Sn},{ }^{13} \mathrm{C}\right) \mathrm{l}$ in $3 \mathrm{a}+3^{\circ} \mathrm{a}(256$ $\mathrm{Hz}$ ) and $3 \mathrm{~b}+3^{\prime} \mathrm{b}(392 \mathrm{~Hz})$, when compared with data for $\mathrm{Me}_{4} \mathrm{Sn}(338 \mathrm{~Hz})$ or $\mathrm{Ph}_{4} \mathrm{Sn}(531 \mathrm{~Hz})$ indicate that the carb substituent is more electropositive than a phenyl or an alkyl group. It is difficult to observe small coupling constants ${ }^{n} \mathrm{~J}\left({ }^{119} \mathrm{Sn},{ }^{13} \mathrm{C}\right)(n>1)$. This is the result of broadening of the ${ }^{13} \mathrm{C}$ NMR signals for carbon atoms not directly adjacent to boron, owing to partially relaxed scalar ${ }^{13} \mathrm{C}-{ }^{11} \mathrm{~B}$ coupling across two or three bonds. However, in the case of $3 \mathrm{~b}$ the vicinal coupling constant ${ }^{3} \mathrm{~J}\left({ }^{119} \mathrm{Sn},{ }^{13} \mathrm{C}(3 / 4)\right)=60 \mathrm{~Hz}$ is resolved. Much larger values $\left.\mathrm{I}^{3} \mathrm{~J}\left({ }^{119} \mathrm{Sn},{ }^{13} \mathrm{C}(3 / 4)\right)\right)$ are observed for $6(\mathrm{Br})$ and $6(\mathrm{Cl})$ (see Figure 2). For the latter compounds, other three-bond and also four-bond ${ }^{119} \mathrm{Sn}-{ }^{13} \mathrm{C}$ coupling constants in the order of 10 to $22 \mathrm{~Hz}$ (see Table 1) are resolved. It is remarkable that the magnitude of the vicinal ${ }^{119} \mathrm{Sn}-{ }^{13} \mathrm{C}(3 / 4)$ coupling constants is so large in comparison with ${ }^{3} \mathrm{~J}\left({ }^{119} \mathrm{Sn},{ }^{13} \mathrm{C}\left(2 / 5-\mathrm{CH}_{3}\right.\right.$ or $\left.\left.-\mathrm{CH}_{2}\right)\right)$. Although, in general, the magnitude of four-bond couplings is smaller than that of three-bond couplings, this is not found in $6(\mathrm{Cl})$ and $6(\mathrm{Br})$.

\section{Conclusions}

Pentaalkyl-6-stannyl-2,3,4,5-tetracarba-nido-hexaboranes(6) (carb-SnR 3 3) are readily accessible by conventional organometallic procedures. The reactivity of $\mathbf{3 b}+\mathbf{3}^{\mathbf{b}} \mathbf{b}$ towards electrophiles showed that the $\mathrm{Sn}-\mathrm{C}$ bonds are cleaved preferably except in the reaction with bromine where a radical mechanism is conceivable. Although these reactions of compounds $3 \mathrm{~b}+$ $3^{\circ} \mathrm{b}$ were not successful with respect to the formation of new element-boron bonds, the derivatives carb-SnCl ${ }_{3} 6(\mathrm{Cl})$ or carb- $\mathrm{SnBr}_{3} 6(\mathrm{Br})$ are new types of inorganic tin(IV) halides, and their chemistry may have a number of interesting aspects for future studies.

\section{Experimental}

All reactions were carried out in an inert atmosphere of $\operatorname{Ar}$ or $N_{2}$, observing necessary precautions to exclude moisture and oxygen. A 2:1 mixture of the isomers 2,4-dimethyl-1,3,5triethyl- and 2,5-dimethyl-1,3,4-triethyl-2,3,4,5-tetracarba-nido-hexaboranes(6) [1] served as starting materials. These were converted into carb-Br $2+2^{\circ}$ [4]. The THF solutions of $\mathrm{Me}_{3} \mathrm{SnLi}$ [10] and $\mathrm{Ph}_{3} \mathrm{SnLi}$ [11] were prepared following literature procedures. The reactions 4.3 to 4.7 were carried out in NMR tubes.

${ }^{1} \mathrm{H},{ }^{11} \mathrm{~B},{ }^{13} \mathrm{C}$ and ${ }^{119} \mathrm{Sn}$ NMR spectra were recorded by using Bruker DRX 500, Bruker AC 300 and Bruker $A R X 250$ instruments equipped with multinuclear probe heads (samples ca. $10-20 \%$ in $\mathrm{C}_{6} \mathrm{D}_{6}$ at $25 \pm 1^{\circ} \mathrm{C}$ in $5 \mathrm{~mm}$ o.d. tubes were measured if not mentioned otherwise). Chemical shifts are given with respect to the chemical shift of the solvent (second external reference $\mathrm{Me}_{4} \mathrm{Si}$ ) $\left[\delta^{1} \mathrm{H}\right.$ $\left.7.15\left(\mathrm{C}_{6} \mathrm{D}_{5} \mathrm{H}\right) ; 7.24\left(\mathrm{CHCl}_{3}\right), \delta^{13} \mathrm{C} 128.0\left(\mathrm{C}_{6} \mathrm{D}_{6}\right) ; 77.0\left(\mathrm{CDCl}_{3}\right)\right]$ and external $\mathrm{Et}_{2} \mathrm{O}-\mathrm{BF}_{3}\left[\delta^{11} \mathrm{~B} 0\right.$ for $\left.\Xi\left({ }^{11} \mathrm{~B}\right)=32.083971 \mathrm{MHz}\right], \mathrm{SnMe}_{4}\left[\delta^{119} \mathrm{Sn} \mathrm{O}\right.$ for $\left.:\left({ }^{119} \mathrm{Sn}\right)=37.290665 \mathrm{MHz}\right]$.

\subsection{Pentaalkyl-6-trimethylstannyl-2,3,4,5-tetracarba-nido-hexaboranes(6) 3a + 3\%a}

6-Bromo-pentaalkyl-2,3,4,5-tetracarba-nido-hexaboranes(6) $2+2^{\circ}(2.2 \mathrm{ml} ; 11 \mathrm{mmol})$ were added to a cooled $\left(-78^{\circ} \mathrm{C}\right)$ solution of $\mathrm{Me}_{3} \mathrm{SnLi}(11 \mathrm{mmol})$ in $50 \mathrm{ml}$ THF. After the reaction mixture was warmed to room temperature and stirred for further $12 \mathrm{~h}$, solid material was filtered off. The solvent was removed in vacuo and the oily residue was distilled to give $3 \mathrm{a}+3^{\circ} \mathrm{a}$ (b.p. $36.5^{\circ} \mathrm{C} / 10^{-4}$ Torr; $2.32 \mathrm{~g} ; 56 \%)$ as a colourless liquid. - ${ }^{1} \mathrm{H}-\mathrm{NMR}$ : $\delta^{1} \mathrm{H}\left[{ }^{n} \mathrm{~J}\left({ }^{119} \mathrm{Sn},{ }^{1} \mathrm{H}\right)\right] 0.08 \mathrm{br}(\mathrm{q}), 0.68 \mathrm{br}(\mathrm{t})(15 \mathrm{H}$, $\mathrm{B}(1)-\mathrm{Et}) ; 1.77\left(\mathrm{~s}, 12 \mathrm{H}, \mathrm{C}\left(2 / 2^{\prime} / 5\right)-\mathrm{Me}\right) ; 1.95$ to 2.07 and 2.14 to $2.28(\mathrm{~m}), 1.11(\mathrm{t}),(10 \mathrm{H}, \mathrm{C}(3 / 4)-\mathrm{Et})$; 1.87 to $2.00(\mathrm{~m}), 0.92(\mathrm{t}),\left(10 \mathrm{H}, \mathrm{C}\left(3^{\prime}\right)-\mathrm{Et}\right) ; 1.87$ to $2.00(\mathrm{~m}), 0.88(\mathrm{t}),\left(10 \mathrm{H}, \mathrm{C}\left(5^{\prime}\right)-\mathrm{Et}\right) ; 1.53(\mathrm{~s}, 6 \mathrm{H}$, $\mathrm{C}(4)-\mathrm{Me}) ; 0.41$ and $0.40(1: 2),\left(\mathrm{s}, 27 \mathrm{H}, \mathrm{SnMe}_{3}\right)[46 \mathrm{~Hz}]$. 


\subsection{Pentaalkyl-6-triphenylstannyl-2,3,4,5-tetracarba-nido-hexaboranes(6) $3 b+3 \mathrm{~b}$}

6-Bromo-pentaalkyl-2,3,4,5-tetracarba-nido-hexaboranes(6) $2+2^{\prime}(1.7 \mathrm{ml} ; 8.3 \mathrm{mmol})$ were added to a solution of $\mathrm{Ph}_{3} \mathrm{SnLi}(8.3 \mathrm{mmol})$ in THF $(25 \mathrm{ml})$ at room temperature. The mixture was stirred for $12 \mathrm{~h}$ at room temperature and then filtered. After removing the solvent, the mixture of $3 b+3^{\circ} b(3.22 g ; 72 \%)$ was obtained as a yellowish wax. - ${ }^{1} \mathrm{H}-\mathrm{NMR}: \delta^{1} \mathrm{H}\left[\left[^{\mathrm{n}} \mathrm{J}\left({ }^{119} \mathrm{Sn},{ }^{1} \mathrm{H}\right)\right] 0.18 \mathrm{br}(\mathrm{q})\right.$, $0.65 \mathrm{br}(\mathrm{t}),(15 \mathrm{H}, \mathrm{B}(1)-\mathrm{Et}) ; 1.77(\mathrm{~s}, 6 \mathrm{H}, \mathrm{C}(2)-\mathrm{Me}) ; 1.76(\mathrm{~s}, 6 \mathrm{H}, \mathrm{C}(2 / 5)-\mathrm{Me}), 1.88$ to 1.96 and 2.23 to $2.31(\mathrm{~m}), 0.95(\mathrm{t}),(10 \mathrm{H}, \mathrm{C}(3 / 4)-E \mathrm{t}) ; 1.81$ to $1.93(\mathrm{~m}), 0.88(\mathrm{t}),(10 \mathrm{H}, \mathrm{C}(3)-E \mathrm{t}) ; 1.93$ to $1.81(\mathrm{~m})$, $0.84(\mathrm{t}),(10 \mathrm{H}, \mathrm{C}(5)-\mathrm{Et}) ; 1.50(\mathrm{~s}, 6 \mathrm{H}, \mathrm{C}(4)-\mathrm{Me}) ; 7.83(\mathrm{~m})[42 \mathrm{~Hz}]$ and 7.17 to $7.27(\mathrm{~m}, 45 \mathrm{H}$, $\left.\mathrm{SnPh}_{3}\right)$. $\mathrm{EI}-\mathrm{MS}(70 \mathrm{eV}): \mathrm{m} / \mathrm{z}(\%)=537(15)\left[\mathrm{M}^{+}\right], 459(25)[\mathrm{M}-\mathrm{Ph}]^{+}, 382(5)[\mathrm{M}-2 \mathrm{Ph}]^{+}, 264(100)[\mathrm{M}-$ $\left.\mathrm{SnPh}_{2}\right]^{+}$.

\subsection{Pentaalkyl-6-chlorodiphenylstannyl- 4(CI), 6-dichlorophenylstannyl-5(Cl) and 6-trichloro- stannyl-2,3,4,5-tetracarba-nido-hexaboranes(6) 6(CI)}

Tin tetrachloride $(0.05 \mathrm{ml} ; 0.394 \mathrm{mmol})$ was added to a solution of $3 \mathrm{~b}+3 \mathrm{~b} \mathbf{b}(0.211 \mathrm{~g} ; 0.394$ mmol) in $\mathrm{C}_{6} \mathrm{D}_{6}$. After 10 minutes, ${ }^{119} \mathrm{Sn}$ NMR spectrum showed signals of carb- $\mathrm{SnPh}_{2} \mathrm{Cl} 4(\mathrm{Cl})$ and carb-SnPhCl $25(\mathrm{Cl})$ besides the carb-SnPh $33 b+3^{\prime} \mathrm{b}$ and phenyltin chlorides. Shortly after the addition of another $0.05 \mathrm{ml}(0.394 \mathrm{mmol})$ of $\mathrm{SnCl}_{4}$ to the reaction mixture, the ${ }^{119} \mathrm{Sn} \mathrm{NMR} \mathrm{signals} \mathrm{of}$ carb-SnPhCl ${ }_{2} 5(\mathrm{Cl})$ as main product and weak signal of carb- $\mathrm{SnPh}_{2} \mathrm{Cl} 4(\mathrm{Cl})$ were detected. After adding a four fold excess of $\mathrm{SnCl}_{4}$, the formation of carb- $\mathrm{SnCl}_{3} 6(\mathrm{CI})$ became evident from its ${ }^{119} \mathrm{Sn} \mathrm{NMR}$ signal, and after $12 \mathrm{~h}$ the carb- $\mathrm{SnCl}_{3} 6(\mathrm{Cl})$ was the only stannyl carborane present. ${ }^{1} \mathrm{H}-N M R(6(\mathrm{Cl}))$ : $\delta^{1} \mathrm{H} 0.03 \mathrm{br}(\mathrm{q}), 0.62 \mathrm{br}(\mathrm{t}),(15 \mathrm{H}, \mathrm{B}(1)-\mathrm{Et}) ; 1.71(\mathrm{~s}, 6 \mathrm{H}, \mathrm{C}(2)-\mathrm{Me}) ; 1.69(\mathrm{~s}, 6 \mathrm{H}$, $\mathrm{C}(2 / 5)-\mathrm{Me}) ; 1.89$ to 1.98 and 2.14 to $2.23(\mathrm{~m}), 1.04(\mathrm{t}),(10 \mathrm{H}, \mathrm{C}(3 / 4)-\mathrm{Et}) ; 1.71$ to $1.93(\mathrm{~m}), 0.86(\mathrm{t})$,. $(10 \mathrm{H}, \mathrm{C}(3)-\mathrm{Et}) ; 1.71$ to $1.93(\mathrm{~m}), 0.84(\mathrm{t}),(10 \mathrm{H}, \mathrm{C}(5)-\mathrm{Et}) ; 1.50(\mathrm{~s}, 6 \mathrm{H}, \mathrm{C}(4)-\mathrm{Me})$.

The reaction with $\mathrm{SnBr}_{4}$ was carried out in the analogous way. The substitution of the last phenyl group didn't take place even after heating the reaction mixture $12 \mathrm{~h}$ to $80^{\circ} \mathrm{C}$. $\delta^{119} \mathrm{Sn}-58.2$ $\left(\mathrm{Ph}_{3} \mathrm{SnBr}\right) ; \delta^{119} \mathrm{Sn}-70.9\left(\mathrm{Ph}_{2} \mathrm{SnBr}_{2}\right) ; \delta^{119} \mathrm{Sn}-224.6\left(\mathrm{PhSnBr}_{3}\right), \delta^{13} \mathrm{C} 137.8$ [966] (Ph-C1130.0 [118]), (Ph-C2/6), 133.3 [78] (Ph-C3/5), 132.6 [25] (Ph-C4). - ${ }^{1} \mathrm{H}-\mathrm{NMR}$ (5(Br)): $\delta^{1} \mathrm{H} 0.13 \mathrm{br}(\mathrm{q}), 0.67 \mathrm{br}(\mathrm{t})$, $(15 \mathrm{H}, \mathrm{B}(1)-\mathrm{Et}) ; 1.80(\mathrm{~s}, 6 \mathrm{H}, \mathrm{C}(2)-\mathrm{Me}) ; 1.80(\mathrm{~s}, 6 \mathrm{H}, \mathrm{C}(2 / 5)-\mathrm{Me}) ; 1.79$ to 1.93 and 2.38 to $2.47(\mathrm{~m})$, $1.05(\mathrm{t}),(10 \mathrm{H}, \mathrm{C}(3 / 4)-\mathrm{Et}) ; 1.75$ to $1.90(\mathrm{~m}), 0.83(\mathrm{t}),\left(10 \mathrm{H}, \mathrm{C}\left(3^{\prime}\right)-\mathrm{Et}\right) ; 1.75$ to $1.90(\mathrm{~m}), 0.80(\mathrm{t})$, (10H, C(5)-Et); 1.45 (s, 6H, C(4)-Me).

\subsection{Reaction of pentaalkyl-6-(triphenyl)stannyl-2,3,4,5-tetracarba-nido-hexaboranes(6) $3 b+3^{\prime} b$ with boron tribromide}

Boron tribromide $(0.05 \mathrm{ml} ; 0.133 \mathrm{~g} ; 0.53 \mathrm{mmol})$ was added to a solution of $3 \mathrm{~b}+3^{\circ} \mathrm{b}$ in $\mathrm{C}_{6} \mathrm{D}_{6}$ $(0.4 \mathrm{ml})$. After $1 \mathrm{~h}$ at room temperature the ${ }^{11} \mathrm{~B}$ NMR signals showed the presence of $\mathrm{Ph}_{2} \mathrm{BBr}\left(\delta^{11} \mathrm{~B}\right.$ 66.2) and starting material. The ${ }^{119} \mathrm{SnNMR}$ spectrum showed along with the signal for the starting material signals for carb- $\mathrm{SnPh}_{3} 3 \mathrm{~b}+3^{\circ} \mathrm{b}, \mathrm{Ph}_{3} \mathrm{SnBr}\left(\delta^{119} \mathrm{Sn}-58.2\right)$ and $\mathrm{Ph}_{2} \mathrm{SnBr}_{2}\left(\delta^{119} \mathrm{Sn}-70.9\right)$ in a ratio 1:1, carb-SnPh $2 \mathrm{Br} 4(\mathrm{Br})$ and carb-SnPhBr $25(\mathrm{Br})$ and a small amount of carb-SnBr $\mathrm{Sr}_{3} 6(\mathrm{Br})$. After the addition of an excess of $\mathrm{BBr}_{3}(0.17 \mathrm{ml} ; 0.45 \mathrm{~g} ; 1.7 \mathrm{mmol})$ to the reaction mixture fast substitution of all phenyl groups at the tin atom took place. This was indicated by a strong ${ }^{119} \mathrm{Sn}$ NMR signal for carb-SnBr $r_{3} 6(\mathrm{Br})$. The ${ }^{11} \mathrm{~B}$ NMR spectrum showed the signal of an excess of $\mathrm{BBr}_{3}$. After heating this solution for $6 \mathrm{~h}$ at $60^{\circ} \mathrm{C}$, the ${ }^{11} \mathrm{~B}$ NMR signals indicated the formation of carb- $\mathrm{Br} 2$ $+2^{\prime}$ and a solid $\left(\mathrm{SnBr}_{2}\right)$ was formed. - 'H-NMR (6(Br)): $\delta^{\prime} \mathrm{H} 0.05 \mathrm{br}(\mathrm{q}), 0.62 \mathrm{br}(\mathrm{t}),(15 \mathrm{H}, \mathrm{B}(1)$-Et); $1.72(\mathrm{~s}, 6 \mathrm{H}, \mathrm{C}(2)-\mathrm{Me}) ; 1.71(\mathrm{~s}, 6 \mathrm{H}, \mathrm{C}(2 / 5)-\mathrm{Me}) ; 1.79$ to 1.93 and 2.26 to $2.43(\mathrm{~m}), 1.04(\mathrm{t}),(10 \mathrm{H}$, $\mathrm{C}(3 / 4)$-Et); 1.73 to $1.83(\mathrm{~m}), 0.79(\mathrm{t}),\left(10 \mathrm{H}, \mathrm{C}\left(3^{\prime}\right)-\mathrm{Et}\right) ; 1.73$ to $1.83(\mathrm{~m}), 0.77(\mathrm{t}),\left(10 \mathrm{H}, \mathrm{C}\left(5^{2}\right)-\mathrm{Et}\right)$; $1.40(\mathrm{~s}, 6 \mathrm{H}, \mathrm{C}(4)-\mathrm{Me})$. 


\subsection{Reaction of pentaalkyl-6-(triphenyl)stannyl-2,3,4,5-tetracarba-nido-hexaboranes(6) $3 b+3 \mathrm{~b}$ with bromine}

Bromine $(0.02 \mathrm{~g} ; 0.10 \mathrm{mmol})$ was added to $0.113 \mathrm{~g}(0.21 \mathrm{mmol})$ of $3 \mathrm{~b}+3^{\prime} \mathrm{b}$ in $\mathrm{C}_{6} \mathrm{D}_{6}(0.4 \mathrm{ml})$. After $12 \mathrm{~h}$ at room temperature ${ }^{11} \mathrm{~B}$ NMR signals for carb-Br $2+2^{\prime}$ indicated cleavage of the $\mathrm{Sn}-\mathrm{B}$ bond, and in the ${ }^{119} \mathrm{Sn} N M R$ spectrum signals for carb- $\mathrm{SnPh}_{2} \mathrm{Br} 4(\mathrm{Br}), \mathrm{Ph}_{3} \mathrm{SnBr}$ and $\mathrm{Ph}_{2} \mathrm{SnBr}_{2}$ were detected as a result of cleavage of the $\mathrm{Sn}-\mathrm{C}$ bond.

4.6 Reaction of pentaalkyl-6-(triphenyl)stannyl-2,3,4,5-tetracarba-nido-hexaboranes(6) $3 b+3 \mathrm{~b}$ with zirconlum tetrachloride

An excess of $\mathrm{ZrCl}_{4}$ was added to a solution of $3 \mathrm{~b}+3^{\prime} \mathrm{b}(0.100 \mathrm{~g} ; 0.18 \mathrm{mmol})$ in $\mathrm{C}_{6} \mathrm{D}_{6}(0.4 \mathrm{ml})$ at room temperature. After $12 \mathrm{~h}$ at $70^{\circ} \mathrm{C}$ there was no reaction observed.

\subsection{Reaction of pentaalkyl-6-(triphenyl)stannyl-2,3,4,5-tetracarba-nido-hexaboranes(6) $3 b+3{ }^{\prime} b$ with tItanium tetrachloride}

An excess of $\mathrm{TiCl}_{4}$ was added to a solution of $3 \mathrm{~b}+3^{\circ} \mathrm{b}(0.104 \mathrm{~g} ; 0.19 \mathrm{mmol})$ in $\mathrm{C}_{6} \mathrm{D}_{6}(0.4 \mathrm{ml})$ at room temperature. After $12 \mathrm{~h}$ at room temperature the ${ }^{119} \mathrm{Sn}$ NMR spectrum of the reaction mixture indicated cleavage of the $\mathrm{Sn}-\mathrm{C}$ bond, by the ${ }^{119} \mathrm{Sn} \mathrm{NMR} \mathrm{signal} \mathrm{of} \mathrm{carb-SnPh}{ }_{2} \mathrm{Cl} 4(\mathrm{Cl})$, in addition to that of the starting material carb-SnPh $3 \mathbf{3 b}+3^{\prime} \mathrm{b}$.

\section{References:}

[1] a) P. Binger Tetrahedron Lett. 24 (1966) 2675;

b) P. Binger, Angew. Chem. 80 (1968) 288; Angew. Chem., Int. Ed. Engl. 7 (1968) 286;

c) R. Köster, M. A. Grassberger, Angew. Chem. 79 (1967) 197; Angew. Chem., Int. Ed. Engl. 6 (1967) 218.

[2] a) T. P. Onak, G. T. F. Wong, J. Am. Chem. Soc. 92 (1970) 5226;

b) V. R. Miller, R. N. Grimes, Inorg. Chem. 11 (1972) 862.

[3] B. Wrackmeyer, G. Kehr, J. Organomet. Chem. 501 (1995) 87.

[4] B. Wrackmeyer, A. Glöckle, Z. Naturforsch. 51b (1996) 859.

[5] M. Herberhold, U. Bertholdt, W. Milius, A. Glöckle, B. Wrackmeyer, J. Chem. Soc. Chem. Commun. (1996) 1296.

[6] a) M. L. Thomson, R. N. Grimes, Inorg. Chem. 11 (1972) 1925;

b) D. K. Srivastava, N. P. Rath, L. Barton, Organometallics 11 (1992) 2263.

c) H. Fang, D. Zhao, N. P. Rath, L. Brammer, L. Barton, Organometallics 14 (1995) 1700.

[7] a) W. Biffar, H. Nöth, R. Schwerthöffer, Liebigs Ann. Chem. (1981) 2067;

b) W. Biffar, H. Nöth, H. Pommerening, R. Schwerthöffer, W. Storch, B. Wrackmeyer, Chem. Ber. 114 (1981) 49;

c) B. Frankhauter, H. Pritzkow, W. Siebert, Z. Naturforsch., 49b (1994) 250.

[8] M. Tanaka, S. Onozawa, T. Sakakura, Y. Hatanaka, IMEBORON IX, Abstracts CB16, Heidelberg, 1996.

[9] I. Omae, Organotin Chemistry, Journal of Organometallic Chemistry Library 21, pp 167 187, Elsevier, Amsterdam (1989).

[10] C. Tamborski, F.E. Ford, E.J.Soloski, J. Org. Chem. 28 (1963) 237.

[11] H. Gilman, O.L. Marrs, S.-Y. Sim, J. Org. Chem. 27 (1962) 4232.

[12] T. Vladimiroff, E. R. Malinowski, J. Chem. Phys. 46 (1967) 1830.

[13] H. A. Bent, Chem. Rev. 61 (1961) 275.

Received: November 7, 1996 - Accepted: December 12, 1996 Accepted in revised camera-ready format: December 20, 1996 
